\title{
Long-term Follow-up
}

National Cancer Institute

\section{Source}

National Cancer Institute. Long-term Follow-up. NCI Thesaurus. Code C16032.

Follow-up activities that continue beyond the active intervention period. 